\title{
Science in Universities: Ordered to Live
}

\author{
M. Murav'eva, special for Acta Naturae
}

\begin{abstract}
An unprecedented act of financial support, in the form of 90 billion rubles for leading Russian universities, has rocked the professional community. With stakes in the development of university science and research, the State has started to take action towards strengthening and amplifying science programs. After determining leading universities (including both research and federal centers) which, in addition to enjoying a high status also receive additional funds, the Ministry of Education and Science has unveiled a new competition for higher educational institutions. This competition focuses on cooperation with business, strengthening the infrastructure needed for innovation, and attracting leading scientists. As early as this fall, the winners are expected to begin receiving funding to the tune of millions of rubles, which should allow them to pursue the most daring and ambitious projects.
\end{abstract}

$\mathrm{I}$ nformation about the significant financial support for Russian universities first emerged late last year at the congress of the United Russia party when Vladimir Putin pledged to allocate an additional 90 billion rubles to universities for the next three years. Later, in January of the current year at the World Conference of Ministers of Education in London, the head of education and science in Russia Andrei Fursenko announced that Russia was embarking on modernization of its higher education, in order to bolster the scientific potential of its universities. He also expressed confidence that the best universities in the country would soon be able to compete not only with the Russian Academy of Sciences, but also with leading laboratories and institutions around the world.

To achieve these goals, the authorities are taking a number of measures. The Ministry of Education plans to spend some additional funds in the following areas:

- Support of development programs for the Moscow and St. Petersburg state universities;

- Support of the modernization ef- fort of federal universities in the fields of scientific research and innovation;

- Support for national research universities;

- Development of cooperation between universities and industrial enterprises;

- Attracting leading researchers to

Russian universities; and

- Developing innovative infrastructure at universities.

\section{LOGICALLY AND CONSISTENTLY}

The planned intention of the State to beef up science at universities has triggered a lively discussion in the scientific community. There was much opposition to the universitybased approach to the development of research in Russia. As an argument, critics of the approach have usually referred to the particularity of the scientific organization in Russia and the traditionally strong position of the Academy. Many people cannot understand why the authorities have suddenly begun actively supporting university science. Yet in fact, there is nothing unexpected in the choice of such a policy. Since the mid 2000s, the Ministry of Edu- cation has been grappling with the stranglehold the Russian Academy of Sciences has on scientific activity, trying to shift the center of gravity of research work towards universities. For many years, science has developed at universities for the most part on their personal initiative, without significant funding from the State. Now, strengthening university science has become a priority that is included in all key documents: in particular, in a document titled Development Strategy for Science and Innovation in Russia, which was passed in February of 2006 and will last until the year 2015. The document states the following: "Separating scientific and educational entities saps their potential for development, limits their contribution to the economy and society, and makes next to impossible full integration into the international scientific and educational community." A need to "integrate the education and research activities" was also mentioned back in 2004 in a presidential address to the Federal Assembly.

The strategy proposes a wide range of measures for the devel- 
opment of university science, first and foremost the establishment of a network of leading research universities, "large, prominent scientific centers, which are equally effective in training specialists at all levels as well as carrying out research and development at an international level." This approach, as well as other ideas, was used nearly five years later (2009-2010) as a basis for selecting research universities.

Among other measures, the strategy points to the need for developing and improving skills, including offering large grants to young scientists to conduct research, purchasing scientific equipment, and creating small startup firms, as well as furthering the mobility of personnel amongst research institutions, universities and various enterprises. Finally, another important stipulation is the need for a developed infrastructure. The State is currently pursuing all of these planned activities in a logical and consistent manner.

\section{LEADERS EXIST}

The reform of higher education, or "modernization" as it is usually called at the Ministry, began with an institutional reform, specifically, with the formation of a group of leading universities.

The Ministry of Education predicts that, over time, there will be no more than 50 universities left in the country, and in total, about 150-200 competitive institutions of higher education. This was mentioned for the first time by Andrei Fursenko two years ago at a meeting with the Russian president at the Moscow Engineering Physics Institute. Around the same time, work began on identifying and forming the country's elite institutions of higher education - both federal and national research centers.

At the moment, there are two federal universities (the Southern and Siberian Universities); there are also five emerging ones: the Volga, Urals, Northern (Arctic), Northeast and Far East. This project, one might say, is geopolitical. The strategic objective for federal universities, which are created by government mandate by combining several universities, is to provide quality education and an opportunity to engage in higher level science, so as to become the scientific and educational centers in their regions. This will allow the economy to develop, and allow qualified specialists to remain in the Far East, Siberia, the Urals, etc.

The mission of the national research universities (NIU) is, firstly, to fill the demand for workers in the high-tech sector, including the nuclear power industry, metallurgy, machine-building, shipbuilding, and others. Secondly, the aim is to develop applied science in order to commercialize research results.

Based on the results of the two contests that were held in late 2009 and early 2010, the status of an NIU was assigned to 29 universities. In addition to the prestigious status, the winners were promised sizable financial aid - 1.8 billion rubles each for five years. Over all, the NIU project will cost the state treasury nearly 50 billion rubles.

Another two schools that have historically been, de facto, the pillars of university education and science are Moscow State University and the St. Petersburg State University, who have also received special powers and very broad rights. By law, they have been given statuses of "the oldest universities in the country with great importance for the development of Russian society."

But even for these "flagships," state support will not be based simply on "giving" money. Moscow State University and St Petersburg State University will receive budget money for specific development programs, just like other research and federal institutions of higher education.

\section{GOVERNMENT STIMULATES}

Selecting a group of leaders was the first serious step in the modernization of higher education in Russia. This step was then followed by additional measures to support research and innovation at universities. "Developing the university research component is one of the top priorities in the state's policy," Deputy Minister of Education and Science Alexei Ponomarev said in a speech: "It is a necessary element of the economy's innovation infrastructure; a mechanism for generating new ideas and technologies, as well as their implementation and replication. Without the participation of universities in research, it is impossible to provide quality training in the areas of priority that are the scientific and technological modernization of Russia. "

In the spring of this year, the Russian government approved three resolutions, № 218, 219, and 220 , to address the most pressing issues affecting domestic science - its aging and the deterioration of the quality of research. According to statistics, at Russian universities, only 15 percent of teachers engage in scientific research; therefore, students also remain remote from science, and without it, their education is essentially meaningless; it turns into daily grinding through outdated textbooks.

Competitions have been announced this summer for each decision. The winners can expect a significant financial infusion that will be aimed at strengthening cooperation between universities and businesses (12 billion rubles for three years), developing the innovation infrastructure (8 billion), and attracting leading scientists (12 billion).

Money is allocated from an anticrisis fund, so that all of the three 
resolutions are dedicated not only to research, but in general, to the modernization of higher education. Accordingly, the Ministry of Education prioritizes problems as follows: 1) Transfer of experience in implementing scientific research in universities to create a climate of healthy competition in Russia;

2) Mobilization of the scientific and management teams so that universities can achieve a qualitative leap in development; and

3) The actual scientific research.

\section{ON COOPERATION BETWEEN UNIVERSITIES AND BUSINESS}

The new tools proposed by the government are designed to make higher education central in applied science, by doing away with the skepticism business has towards the quality of their research. The State is trying to find ways to integrate higher education into the economy. This is true not only for the performance of individual economic agreements, as was the case before, but also for the implementation of strategic plans for the development of Russian companies. Decree № 218 contains a list of the 54 largest public and private companies that have to come up with programs of innovation development incorporating interaction with universities by November of this year. Deputy Minister Alexei Ponomarev has predicted that in the near future 20-30 companies out of 54 will begin cooperating with universities. This will be the basis for the establishment of so-called technology platforms - conglomerates of leading industrial firms, universities, and regional administrations. This tool, which has been borrowed from the European Union, is not directly supported by state resources. The point is to create consulting entities generated by key customers and engaging in research and development on certain issues. The entities in such platforms will be engaged in planning and forecasting in their areas of specialization, market research, and elaboration of solutions that will shape government policy.

According to the Ministry of Education, it is extremely important to encourage both universities and commercial enterprises to invest in the development of the high-tech industry. The most significant tool given to the agency is the subsidies to industrial firms in order to work with institutions of higher education. Nineteen billion rubles are allocated for that purpose, six in 2010. Any firm, including foreign ones, that managed to have their research and development projects reviewed by experts from the institutions were invited to participate in the contest, which was announced in late June as stipulated in the 218th decree. The subsidy will be available for a period of 1 to 3 years and can amount to up to 100 million rubles per year. Companies are required to come up with matching funds of no less than the amount received from the State.

The contest proved very attractive for business: applications were lodged by 416 organizations from 59 Russian regions. One hundred and fifty-seven schools were selected as the projected sites for research and development in the project. The total amount sought by grant applicants exceeds 70 billion rubles. The average size of a subsidy is approximately 150 million rubles.

Fifty-seven projects won grants; 33 of the projects will be conducted in the regions that are not part of Moscow and St. Petersburg. Among the winners were such large manufacturing companies as the aircraft corporation MiG, truck builder KAMAZ, diamond mining giant ALROSA, and others. In total, 55 companies, in cooperation with 49 Russian universities, will implement the projects.

It is worth noting that the competition is conducted in two phases.
The decision was dictated by the desire to hit the targeted number of applications, since not all organizations had time to prepare the necessary paperwork. The results of the second phase will be announced before October 5.

Government Decrees № 218 and 219 are considered in the academic circle as the second stage of the push toward innovation at Russian universities. The first one was associated with small businesses -with 217-FZ becoming law last year, which allowed universities to establish small businesses. Now is the time for a stronger big business sector, which will be commissioning research and innovation from universities.

\section{DEVELOPMENT OF THE INFRASTRUCTURE FOR INNOVATION}

Based on government Decree 219, a selection of various university programs focusing on developing innovation infrastructure was carried out. Some 199 universities took part in the competition. The winner was determined by an analysis of the scientific, educational and innovative potential of the institution over the past 3 years and was presented based on these development programs. The Competition Commission selected the 56 best institutions. Most of them (14) are universities located in Moscow (Moscow State University, Bauman Moscow State Technical University, Moscow Institute of Physics and Technology, Moscow Engineering Physics Institute, Moscow Institute of Electronic Technology, and others). But over all, the geography of the winners is wide - 36 Russian regions in all 8 of the federal districts: Far East - 4; Volga - 7; North-West - 7; North Caucasus - 3; Siberian - 8; Ural 4; Central - 20; and South - 3.

Each higher educational institution will receive up to 150 million rubles. The funds can be spent on strictly defined areas: 
1) The development of the innovation infrastructure: business incubators, technology parks, certification centers, technology transfer, shared-use scientific and technical information, and others;

2) Evaluation of the results of intellectual activities and their legal protection;

3) Implementation and development of targeted training and skills development in small innovative enterprises, including graduate students and young scientists, as well as developing educational-methodological, and scientific-methodological support for small and mediumsized enterprises;

4) Training and professional development of university staff in the field of innovative entrepreneurship and technology transfer at foreign universities;

5) Consulting services of foreign and Russian experts in the field of technology transfer; creation and development of small innovative companies, including involving faculty members in the normativemethodical and practical support in the creation of such companies.

\section{ATTRACTING TOP SCIENTISTS}

Decree 220 is meant to attract the best specialists in the world to universities on a competitive basis to work at the newly established laboratories. To achieve this, the federal government will allocate 12 billion rubles. Given that the size of a single grant is 150 million, up to $80 \mathrm{sci}-$ entists could win grants.

Some 507 applications have been received from 179 universities in the competition. Of these, most are in the following fields: Physics, Information Technology and Computing Systems, Earth Sciences and Materials Science (40 each), and only five are in the field of Agricultural Sciences and Engineering.

Competition is intense amongst universities, especially since some of them have filed multiple applications. Lomonosov Moscow State University stands out with 30 applications. St. Petersburg State University and the Moscow Engineering Physics Institute have filed 21 applications, each. The vast majority of universities only submitted 3 to 6 applications.

The Ministry of Education has repeatedly emphasized that leading scientists will be determined not according to their countries of origin; the purpose of the contest is not to attract foreigners. The main goal is to secure real scientific achievements. However, many universities rely on foreign scientists. There are about 130 contenders for the multimillion-ruble grant.

Invited scholars will have to lead a newly created laboratory and work there for at least four months a year. As explained on the eve of the contest by officials of the Ministry of Education, when considering applications, experts will first look not at what research the higher educational institution is able to offer, but in fact, whether the implementation of this proposal will create a world-class laboratory. Under the project's performance guidance, the Ministry of Education wants to create a laboratory that will be able to operate efficiently and successfully after the completion of the project (three years), with a staff able to publish articles in prestigious scientific journals, secure orders from commercial firms, register patents on designs and win in new contests, etc.

Unlike other government initiatives, the idea of attracting leading scientists to Russian universities has been the one that has ruffled most feathers in the local scientific community. There are many critics and skeptics, and those who generally support the idea have reservations as to how it will be implemented; in particular, whether a competent and honest examination of the applications and, accordingly, the picking of winners, will be possible. How justified these concerns are will become clear when the results of this competition are announced. By then, it will be possible to assess the quality of the winning bids and, therefore, the scientists who will have to create world-class laboratories.

Thus, the government supports university science, not only through the size of the funding for the universities, which are awarded different statuses, but also through related initiatives. Thus, the State seeks to improve the quality of training at Russian universities, develop the research and technological bases of universities, and bolster their innovative dimention.

Skeptics fear that universities will be unable to cope with the tasks and that the money and equipment will fall into the hands of those less able to use them effectively. To such criticism, the leadership of the Ministry of Education has only one answer; resources will be allocated to universities only on the basis of merit and cause. The winners will have to win in a tough competition. No carefree life is promised. And if a university begins losing position throughout the course of the program, it can lose its status. In this case, there is no choice but to believe the word of the officials. Let's see what comes out of this grandscale project and who, in the end, turns out to be right - the skeptics or optimists. 